\title{
Communication
}

[Comunicação]

\section{An unusual gangrenous goat mastitis caused by Staphylococcus aureus, Clostridium perfringens and Escherichia coli co-infection}

\author{
[Mastite gangrenosa caprina atípica causada por co-infecção \\ por Staphylococcus aureus, Clostridium perfringens e Escherichia coli] \\ M.G. Ribeiro, G.H.B. Lara, S.D. Bicudo, A.V.G. Souza, \\ T. Salerno, A.K. Siqueira, J.S. Geraldo \\ Faculdade de Medicina Veterinária e Zootecnia - UNESP \\ Caixa Postal 560 \\ 18618-000 - Botucatu, SP
}

Mastitis is considered one of the most important diseases of domestic animals, caused by several etiologic agents. Transmission of the microorganisms primarily occurs by ascendant via in canal of teats, usually involving agents from animals and environmental origin and from milking process (Anderson et al., 2005). Staphylococcus aureus is recognized as the most common causal agent of goat mastitis, followed by minor occurrence of Mannheimia (Pasteurella) haemolytica, Escherichia coli, Clostridium perfringens, Streptococcus, Pseudomonas and Nocardia genera (Bergonier et al., 2003, Radostits et al., 2007), including in Brazil (Megid et al., 1990, Ribeiro et al., 1998).

Gangrenous mastitis in goats is a severe clinical condition of the inflammatory process in mammary glands. Clinical signs commonly occur in the first weeks of lactation, committing one or two sides of the glands and are characterized by fever, anorexia, dyspnea and systemic signs of toxemia. Initially, the udder is hot, painful and occurs swelling of the affected side, with milk watery, containing flocculent pus and/or blood secretion. Evolution of the process is characterized by udder becoming discolored (blue-blackish or blue-greenish), cold, with demarcation line of the affected tissue, development of abscess and draining pus. Fatal clinical course is characterized by worse of corporal condition, pneumonia, septicemia and/or toxemia. Usually, gangrenous goat mastitis is associated with $S$. aureus or $M$. haemolytica infections. Treatment involves antimicrobial and anti-inflammatory drugs associated with fluid therapy, surgical drainage, debridation and demotion of necrosis tissue (Cable et al., 2004). The present report describes an unusual case of combined infection by $S$. aureus, E. coli and C. perfringens isolated from gangrenous mastitis in goat.

A three-year-old goat, Boer breed, was referred to the Veterinary Hospital, presenting peracute clinical signs of mastitis in the right side of mammary gland, two weeks after the parturition. In the clinical exam, fever, anorexia and dyspnea were observed. The mammary gland was bluegreenish, cold, with marked line of the affected tissue and milk containing blood and pus secretion (Figure 1). No evidence of traumatic lesions or foreign body was observed during the clinical exam in mammary gland.

Milk samples were aseptically collected and submitted to microbiological culture on defibrinated sheep blood agar (5\%), MacConkey agar and Sabouraud agar, incubated under aerobiosis, at $37^{\circ} \mathrm{C}$ for $72 \mathrm{~h}$. The same material was submitted to sheep blood agar $(5 \%)$, incubated under anaerobic conditions, at $37^{\circ} \mathrm{C}$ for $120 \mathrm{~h}$. Microorganisms isolated were identified based on macro and microscopical morphology by Gram stain, culture characteristics and biochemical profile (Krieg

Recebido em 4 de abril de 2006

Aceito em 21 de maio de 2007

E-mail: mgribeiro@fmvz.unesp.br 
and Holt, 1984; Quinn et al., 1994). Cytological smears of milk stained by Gram and Giemsa revealed combined infection characterized by numerous Gram-positive cocci and rods and Gram-negative rods microorganisms. Goldenyellowish, circular, beta-hemolytic colonies associated to grayish, non-hemolytic colonies were obtained after $24 \mathrm{~h}$ on sheep blood agar, while on MacConkey agar, pink colonies (lactose-positive) were observed in pure cultures

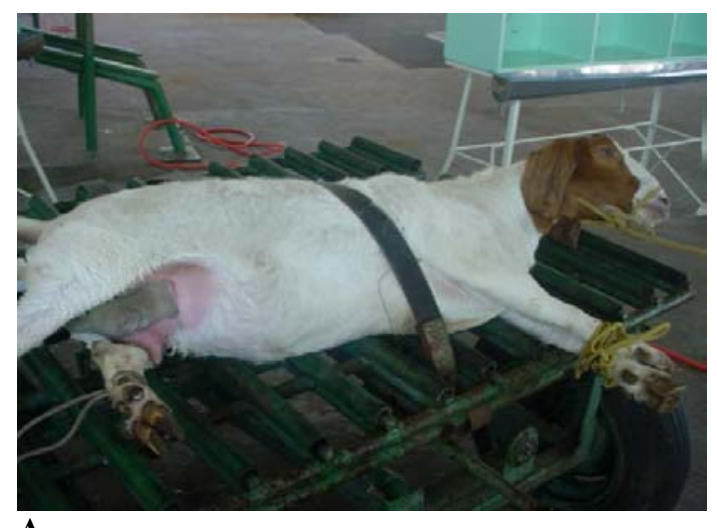

A

Figure 1. A) Severe gangrenous mastitis in goat of Boer breed, caused by Staphylococcus aureus, Escherichia coli and Clostridium perfringens co-infection; B) Detail of mammary lesion, Botucatu, SP, Brazil.

S. aureus and E. coli isolates were submitted to in vitro drugs susceptibility test using disk diffusion method (Bauer et al., 1966) and showed susceptible to ampicillin $(10 \mu \mathrm{g})$, enrofloxacin $(5 \mu \mathrm{g})$ and gentamicin $(10 \mu \mathrm{g})$.

Treatment was initially attempted using ampicillin $(22 \mathrm{mg} / \mathrm{kg}, 8 \mathrm{~h}, \mathrm{SC})$ and enrofloxacin $(10 \mathrm{mg} / \mathrm{kg}, 24 \mathrm{~h}, \mathrm{SC})$, associated to flunixin meglumin $(1.1 \mathrm{mg} / \mathrm{kg}, 24 \mathrm{~h}, \mathrm{SC})$. In despite of initial therapy, the animal was submitted to unilateral mastectomy (Cable et al., 2004) 24h after the clinical exam, due to worsen of general clinical signs and extension of the mammary lesions (Figure 1). Histopathological evaluation of mammary tissue after mastectomy revealed severe acute inflammatory process, characterized by numerous neutrophils, necrotizing tissue and pus, containing cocci and rods microorganisms. Fragments of mammary gland were submitted to microbiological culture and revealed the same microorganisms isolated from milk. Mastectomy is a choice procedure in gangrenous mastitis in goats (Cable et al, 2004). From a similar way, mastectomy associated to anti-inflammatory and after 24h. Biochemical tests characterized golden-yellowish colonies on sheep blood agar as $S$. aureus, and pink colonies on MacConkey agar as E. coli. After five days of incubation under anaerobic conditions, smooth, round, glistening colonies, surrounded by "target" or double hemolysis were verified on sheep blood agar, and the agent was identified as $C$. perfringens.

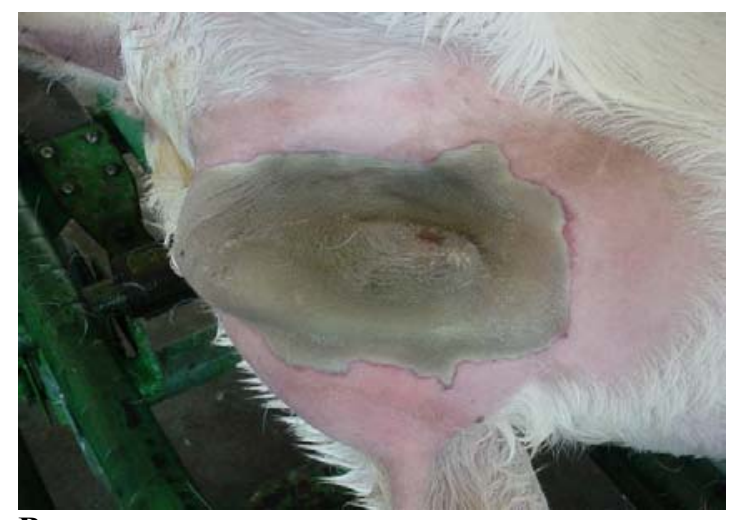

antimicrobial drugs therapy in the present case also showed to be effective. No evidence of lesion or foreign body was observed during the clinical exam of the goat mammary gland which suggests a traumatic introduction of the agents. Thus, the mammary infection in the present report probably occurred via ascendant by the teat canal, described as principal form of transmission in domestic animals (Radostits et al., 2007).

$S$. aureus is recognized as the most-common agent of mastitis in domestic animals, including gangrenous presentations in small ruminants (Anderson et al., 2005). E. coli and $C$. perfringens are considered as the minor occurrences in mammary infections of small ruminants, although they have been associated to serious mastitis cases. In the present case, severe clinical mastitis with systemic signs produced by $S$. aureus, $C$. perfringens and $E$. coli probably occurred due to the action of different cytotoxins and endotoxins that led to extensive tissue damage and systemic reaction in the animal (Quinn et al., 1994, Radostits et al., 2007). 
The identification of different causal agents associated to mammary infections in small ruminants has been reported (Anderson et al, 2005, Radostits et al., 2007). However, combined infection by $S$. aureus, $C$. perfringens and $E$. coli in gangrenous mastitis in goats is reported by the first time in Brazil and also in the consulted literature.

Keywords: goat, gangrenous mastitis, etiology, co-infection

\section{RESUMO}

Relata-se, pela primeira vez no Brasil, a ocorrência de mastite gangrenosa caprina atípica causada pela co-infecção por Staphylococcus aureus, Clostridium perfringens e Escherichia coli em uma cabra da raça Boer, na segunda semana de lactação. Descrevem-se os achados clínicos, os procedimentos de diagnóstico microbiológico e a conduta terapêutica.

Palavras-chave: cabra, mastite gangrenosa, etiologia, co-infecção

\section{REFERENCES}

ANDERSON, D.E.; HULL, B.H.; PUGH, D.G. Enfermidades da glândula mamária. In: PUGH, D.G. (Ed). Clínica de Ovinos e Caprinos. São Paulo: São Paulo, 2005. p.379-399.

BAUER, A.W.; KIRBY, W.M.M.; SHERRIS, J.C. et al. Antibiotic susceptibility testing by a standardized single disk method. Am. J. Clin. Pathol., v.45, p.493-496, 1966.

BERGONIER, D.; CREMOUX, R., RUPP, R. et al. Mastitis in dairy small ruminants. Vet. Res., v.34, p.689-716, 2003.

CABLE, C.S.; PEERY, K.; FUBINI, S.L. Radical mastectomy in 20 ruminants. Vet. Surg., v.33, p.263-266, 2004.

KRIEG, N.R.; HOLT, J.G. Bergey's Manual of Systematic Bacteriology. London: Williams \& Wilkin, v.1, 1984. 984p.
MEGID, J.; FREITAS, J.C.; BRACARENSE, A.P.F.R.L. et al. Mamite caprina por Nocardia asteroides. Arq. Bras. Med. Vet. Zootec., v.42, p.545-547, 1990.

QUINN, P.J.; CARTER, M.E.; MARKEY, B. et al. (Eds). Clinical Veterinary Microbiology. London: Wolfe, 1994. 648p.

RADOSTITS, O.M.; GAY, C.C.; HINCHCLIFF, K.W. et al. (Eds). Veterinary Medicine - A Textbook of the Diseases of Cattle, Horses, Sheep, Pigs, and Goats. 10. ed. Philadelphia: Saunders, 2007. p.673-762.

RIBEIRO, M.G.; MEGID, J.; MEIRA, D.R. et al. Mastite caprina. Estudo microbiológico, físico-químico e de diagnóstico através de provas indiretas. Biológico, v.61, p.27-33, 1998. 